\title{
Movement Patterns of Carbon from Source to Sink in Cranberry
}

\author{
Teryl R. Roper ${ }^{1}$ and John S. Klueh ${ }^{2}$ \\ Department of Horticulture, University of Wisconsin-Madison, 1575 Linden Drive, Madison, \\ WI 53706-1590
}

Additional index words. photoassimilate, radioactive labeling, Vaccinium macrocarpon

\begin{abstract}
The source of photosynthate for developing cranberry (Vaccinium macrocarpon Ait.) fruit can be partitioned spatially among new growth acropetal to fruit, 1-year-old leaves basipetal to fruit, and adjacent uprights along the same runner. Cranberry uprights were labeled with ${ }^{14} \mathrm{CO}_{2}$ in an open system with constant activity during flowering or fruit development. When new growth acropetal to fruit was labeled, substantial activity was found in flowers or fruit. Little activity was found in basipetal tissues. When 1-year-old basipetal leaves were labeled, most of the activity remained in the labeled leaves, with some activity in flowers or fruit. Almost no labeled $\mathrm{C}$ moved into acropetal tissues. When new growth of adjacent nonfruiting uprights on the same runner were labeled, almost no activity moved into the fruiting upright. These data confirm that new growth acropetal to developing flowers and fruit is the primary source of photosynthate for fruit development. Furthermore, they show that during the short time studied in our experiment, almost no C moved from one upright to another.
\end{abstract}

The cranberry of commerce is a low-growing evergreen vine. Fruit are borne on short vertical shoots called uprights. Flowers and fruit develop on the basal portions of current-season growth and, thus, develop between new growth that is acropetal and 1year-old leaves that are basipetal.

The source of photosynthate for developing cranberry fruit can be partitioned spatially among new growth acropetal to fruit, 1year-old leaves basipetal to fruit, and adjacent uprights along the same runner. Our previous research indirectly sought to determine which of these three sources of photosynthate is the most important for supporting developing fruit (Roper et al., 1992; Roper and Klueh, 1994). Removing growth acropetal to fruit at the time of fruit set was more detrimental than removing 1-year-old leaves basipetal to developing fruit. Our research was undertaken to examine the movement of $\mathrm{C}$ from potential sources to developing flowers and fruit.

\section{Materials and Methods}

Experiments were conducted on sods of mature 'Searles' cranberry from commercial cranberry beds in central Wisconsin. Sods were obtained on 17 June 1994, which was before bloom, and were acclimated in a cold frame with ambient conditions. Each sod was $\approx 35 \times 60 \times 15 \mathrm{~cm}$ and included 6 to $10 \mathrm{~cm}$ of soil along with intact vines. The sods were placed in heavy flats for transport and handling. Sods were preacclimated in a greenhouse for 1 day before labeling. Flowers were pollinated by hand several times per week to set the maximum amount of fruit possible (Birrenkott and Stang, 1989).

${ }^{14}$ Carbon labeling was performed at two stages of development (timings). Labeling began when early flowers were fully open with

Received for publication 4 Dec. 1995. Accepted for publication 17 Apr. 1996. This research was supported by College of Agricultural and Life Sciences Hatch Project 3305. We acknowledge and appreciate the cooperation of Tom Sharkey and Peter Vanderveer of the Univ. of Wisconsin-Madison Dept. of Botany in conducting these experiments and Su Debaene-Gill for statistical analysis. The cost of publishing this paper was defrayed in part by the payment of page charges. Under postal regulations, this paper therefore must be hereby marked advertisement solely to indicate this fact.

1Associate Professor.

2Former Assistant Researcher. the petals recurved. A second labeling on different uprights began when the basal fruit on uprights were almost full sized but were still green. This timing was $\approx 4$ weeks after the initial experiment. At least five uprights were labeled per stage of development and source of $\mathrm{C}$ at each stage of development.

Portions of flowering or fruiting uprights acropetal or basipetal to flowers or fruit or a nonflowering upright immediately adjacent to a flowering or fruiting upright were enclosed in a double-sided (gas provided to both sides) clamp on a $5.5-\mathrm{cm}^{2}$, aluminum, watercooled cuvette. Cuvette temperature was maintained at $25.5 \pm 1^{\circ} \mathrm{C}$. Enclosed leaf area ranged between 3.3 and $4.5 \mathrm{~cm}^{2}$. The chamber was illuminated with $600 \mu \mathrm{mol} \cdot \mathrm{m}^{-2} \cdot \mathrm{s}^{-1}$ with a lamp (KL 1500; Schott Glaserke, Wiesbaden, Germany) with fiber optics. Assimilation of unlabeled $\mathrm{CO}_{2}$ was monitored, using a infrared gas analyzer (LI-COR 6251; LI-COR, Lincoln, Neb.), until a steady rate was achieved. The upright portion was then fed ${ }^{14} \mathrm{CO}_{2}$ (specific activity $61 \mathrm{kBq} / \mathrm{mm}$ ) for $20 \mathrm{~min}$. Feeding was followed by about a 20-min exposure in the chamber to unlabeled $\mathrm{CO}_{2}$ to clear the chamber. The partial pressure of labeled and unlabeled $\mathrm{CO}_{2}$ was 35 $\mathrm{Pa}$.

Following labeling, the sods were moved to the greenhouse. For samples labeled on adjacent uprights, a 3- or 4-day chase in ambient air was allowed to give adequate time for photosynthate to move from source to sink. For samples labeled immediately above or below flowers or fruit, a 1-day chase followed labeling. Following the ambient air chase, three treated uprights per treatment were removed and placed on Kodak SB5 film (Eastman Kodak, Rochester, N.Y.) and stored in a freezer at $-80{ }^{\circ} \mathrm{C}$ for several weeks for the film to be exposed. Following exposure, individual uprights were separated into three fractions (acropetal, basipetal, and flowers or fruit) and placed in scintillation cocktail (Bio-Safe II, Research Products Intl., Mount Prospect, Ill.) for counting. The remaining two samples were stored at $-80^{\circ} \mathrm{C}$ and then fractioned and counted as the samples that were used for autoradiography. Although counting efficiency from intact plant tissues is not as great as for combustion or digestion techniques, the simple method we present in this paper resolves importing and exporting portions of uprights (Robinson-Beers et al., 1990).

The experiment was analyzed as a split-plot design with upright portion treated as the main plot and time as the split plot. Data were square-root transformed before analysis of variance. 


\section{Results and Discussion}

This method of introducing ${ }^{14} \mathrm{C}$ into cranberry plants was highly successful. Patterns of ${ }^{14} \mathrm{C}$ movement within vines were plainly evident. Background levels of radioactivity were $\approx 14 \mathrm{dpm}$. When ${ }^{14} \mathrm{C}$ was introduced to young leaves acropetal to flowers, significant amounts of activity remained within the labeled tissue. Radioactivity found in flowers was $\approx 70 \%$ of that found in the labeled tissues (Table 1). Little labeled $\mathrm{C}$ moved below the flowers into 1-year-old leaves. The same pattern was evident 4 weeks later when fruit were developing. Substantial amounts of labeled C moved from acropetal tissues into developing fruit. There was almost no activity in basipetal tissue below fruit.

Significantly more ${ }^{14} \mathrm{C}$ was translocated into developing fruit than flowers (Table 1). This movement was accompanied by less ${ }^{14} \mathrm{C}$ remaining in the labeled tissue during fruiting than flowering.

When ${ }^{14} \mathrm{C}$ was introduced into 1-year-old leaves basipetal to flowers, most of the label remained in the labeled tissue, with a small amount translocated to the flowers and new growth above the flowers (Table 1). Once fruit were developing, the pattern was very similar, with most of the radioactivity remaining in the labeled leaves and very little moving into the fruit. There was no difference between the amount of label translocated to flowers compared to fruit from the basipetal tissues

Label introduced into an adjacent nonfruiting upright along the same runner did not translocate into vegetative tissues of a flowering or fruiting upright at levels significantly above background during flowering (Table 1). Once fruit were developing, however, activity above background was detected in the fruit.

It is clear from these data that the new growth acropetal to developing flowers or fruit is the primary source of $\mathrm{C}$ for fruit development. This supports Hagidimitriou and Roper's (1995) conclusions, who found photosynthetic rates of new leaves were double those of 1-year-old leaves basipetal to fruit. This observation also supports the results of leaf removal studies showing that removing growth acropetal to developing fruit was more deleterious to fruit set and yield than removing 1-year-old basipetal leaves (Roper et al., 1992; Roper and Klueh, 1994).

These data show that there is no difference in $\mathrm{C}$ movement from 1 -year-old leaves to developing fruit or flowers. If the sink strength of developing flowers and fruit increases over time, then more label should have been translocated to developing fruit compared to developing flowers. While numerically this is so, the differences are nonsignificant. There were no significant interactions among tissue treated, tissue sampled, and time of treatment.

Current-season growth acropetal to developing fruit clearly is the major source of photosynthate for fruit development. Anything that would inhibit photosynthesis in this tissue potentially will reduce yields.
Table 1. Radioactivity counted in acropetal, flower, fruit, or basipetal tissues following assimilation of ${ }^{14} \mathrm{CO}_{2}$ by leaves either acropetal or basipetal to fruit on the same upright or on an adjacent nonfruiting but connected upright $(\mathrm{n}=5){ }^{\mathrm{z}}$

\begin{tabular}{|c|c|c|c|c|}
\hline \multicolumn{2}{|c|}{${ }^{14} \mathrm{C}$ labeling } & \multicolumn{3}{|c|}{ Tissue sampled and $14^{\circ} \mathrm{C}$ count $(\mathrm{dpm})$} \\
\hline $\begin{array}{l}\text { Tissue } \\
\text { location }\end{array}$ & Timing & Acropetal & $\begin{array}{l}\text { Flowers/ } \\
\text { fruit }\end{array}$ & Basipetal \\
\hline Acropetal & Flowering & $7,709 a^{*}$ & $5,592 \mathrm{a}^{*}$ & $222 \mathrm{~b}$ \\
\hline Acropetal & Fruiting & $4,824 \mathrm{~b}$ & $10,527 \mathrm{a}$ & $118 \mathrm{c}$ \\
\hline Basipetal & Flowering & $27 \mathrm{~b}$ & $342 \mathrm{~b}$ & $4,308 \mathrm{a}$ \\
\hline Basipetal & Fruiting & $180 \mathrm{~b}$ & $957 \mathrm{~b}$ & $3,827 \mathrm{a}$ \\
\hline Adjacent & Flowering & $20^{*}$ & 54 & 32 \\
\hline Adjacent & Fruiting & $14 \mathrm{~b}$ & $126 \mathrm{a}$ & $27 \mathrm{~b}$ \\
\hline
\end{tabular}

${ }^{\mathrm{z}}$ Within rows, mean separation by Duncan's new multiple range test $(P \leq 0.05)$.

${ }^{*}$ Significant differences between timings of ${ }^{14} \mathrm{C}$ labeling of the same tissue. Mean separation by Duncan's new multiple range test $(P \leq 0.05)$.

\section{Literature Cited}

Birrenkott, B.A. and E.J. Stang. 1989. Pollination and pollen tube growth in relation to cranberry fruit development. J. Amer. Soc. Hort. Sci. 114:733-737.

Hagidimitriou, M. and T.R. Roper. 1995. Seasonal changes in $\mathrm{CO}_{2}$ assimilation of cranberry leaves. Scientia Hort. 64:283-292.

Robinson-Beers, K., T.D. Sharkey, and R.F. Evert. 1990. Import of ${ }^{14} \mathrm{C}$-photosynthate by developing leaves of sugarcane. Bot. Acta 103:424-429.

Roper, T.R. and J.S. Klueh. 1994. Removing new growth reduces fruiting in cranberry. HortScience 29:199-201.

Roper, T.R., E.J. Stang, and G.M. Hawker. 1992. Early season leaf removal reduces fruit set and size in cranberry. HortScience 27:75. 